\title{
Devils, the Divine, and the Dual Despair in Doctor Faustus
}

\author{
MELISSA PULLARA \\ CARLETON UNIVERSITY
}

Aside from wondering why Hamlet delays his revenge, the other issue that has perhaps most captivated and confounded scholars of early modern drama is Faustus' damnation. Why is he damned? Must he indeed be damned? Is it a matter of election or does he damn himself through his actions? In addition to debating the role of Calvinist predestination in the play, several scholars have argued that Faustus' spiritual despair is key to his damnation, regardless of matters of election. ${ }^{1}$ If his fate is not, in fact, sealed from the beginning, then it is his despair in believing he is damned beyond redemption that prevents him from seeking repentance from God. If he is predestined, then his despair is confirmation of his internal reprobation. Either way, a despairing Faustus cannot be saved.

While many scholars have focused on the religious despair in Marlowe's play, I argue that Faustus' experience of despair is two-fold: it is a religious despair for the fate of his soul, but also an intellectual despair. I define his intellectual despair as his difficulty reconciling spiritual mysteries about God and heaven with knowledge based in study of the physical world. Throughout the play, Marlowe parallels the two by rooting Faustus' understanding of the spiritual world in his focus on the physical world. In so doing, Marlowe anticipates the fundamental basis of Francis Bacon's seventeenth-century natural philosophy, wherein he advocates for discovering spiritual truth about God through the empirical study of God's creation. However, Faustus lacks such intellectual postulates to guide him. Instead, he manifests medieval fears about intellectual curiosity by seeking to use magic to exceed the empirical study he believes he has already academically mastered, and to delve into abstract celestial truths which extend beyond the limitations of human knowledge. Faustus soon discovers the reality of these limitations himself, as he fails in his attempts to use the structures of academic study to understand the divine, leaving him with a debilitating sense of his capability for intellectual mastery.

His turn to the demonic for assistance further reinforces his own uncertainty, both about his intellectual abilities and about how his ambitious curiosity has affected, or in the

\footnotetext{
${ }^{1}$ See for example Arieh Sachs, "The Religious Despair of Doctor Faustus," The Journal of English and Germanic Philology 6, no. 4 (1964): 625-47 and Pompa Banerjee, "I, Mephastophilis: Self, Other, and Demonic Parody in Marlowe's Doctor Faustus," Christianity \& Literature 42, no. 2 (1993): 221-41.
} 
case of predestination, confirmed, the fate of his soul. The appearance of the devils sets Faustus on a collision course where his religious despair for his soul both occurs alongside and comes up against his intellectual despair of his diminishing belief in his capability for acquiring knowledge. The more he engages with Mephistopheles, in order to persuade himself that he yet maintains the capability for intellectual mastery, the more he discovers his spiritual and intellectual frailties. Faustus' build-up of uncertainty comes to a head in the eleventh hour when his concerns about his soul dissolve into thoughts of the natural worldthe elements on which he once focused his studies. At the end, Faustus looks not to Lucifer or God but to the earthly to shield and comfort him. The full-circle return of his focus to empirical matters suggests that if Faustus could indeed return to the first act he would be best served consuming himself with God's creation, rather than the mysteries of God Himself. By studying the former, the latter are implicitly revealed in ways that are accessible to the limited human mind, while a purely rational interrogation of celestial truths can yield selfdoubt and despair.

The Elizabethan understanding of the differentiation between physical and metaphysical worlds had its roots in Aristotle's work on scientia, where he identifies the separation between natural philosophy and the "divine science" of metaphysics. Natural philosophy was "concerned with changeable material objects that were independent of the human mind" and relied on "demonstrative truths" in the material world for the discovery of knowledge. Metaphysics, on the other hand, focused on "immaterial, unchangeable objects that were independent of the human mind."2 In his Novum Organum, Francis Bacon advocates for a new science that attempts to marry Aristotle's distinct categories - a natural philosophy wherein new scientific discoveries in nature "provided irrefutable evidence of divine design" and of the mysteries of God Himself. ${ }^{3}$ Bacon's use of the term "nature" tends to refer to the physical material world, the scientific elements and species which become subjects of empirical experimentation. When I discuss Faustus' ties to and mastery over the natural, physical world, I refer more to Robert Watson's definition in Back to Nature: "the totality of the physical universe."4 I argue that this encompasses both the laws of nature and

\footnotetext{
${ }^{2}$ Peter Harrison, "Physico-Theology and the Mixed Sciences," in The Science of Nature in the Seventeenth Century: Patterns of Change in Early Modern Natural Philosophy, ed. Peter R. Anstey and John A. Schuster (New York: Springer, 2005), 166-67.

${ }^{3}$ Peter Harrison, "Natural Theology, Deism, and Early Modern Science," in Science, Religion, and Society: An Encyclopedia of History, Culture, and Controversy, ed. Arri Eisen and Gary Laderman (New York: Routledge, 2007), 428.

${ }^{4}$ Robert Watson, Back to Nature: The Green and the Real in the Late Renaissance (Philadelphia: The University of Pennsylvania Press, 2006), 8.
} 
the laws of man, so that when Faustus boasts of his legal expertise, for example, his sense of mastery nonetheless stems from a knowledge of the physical world and those in it. ${ }^{5}$

Bacon's ideas were not revolutionary, as these notions about the link between the natural and divine were pre-dated and informed by ideas about the link between the natural and the occult (indeed, magic and science could be said to be but points on a spectrum). These ideas were still prevalent in the early modern period. An early biographer of William Perkins, for example, wrote that before Perkins became renowned for his views against witchcraft, he was "much addicted to the studie of naturall magicke, digging so deepe in natures mine, to know the hidden causes and sacred qualities of thinges." ${ }^{\prime 6}$ Perkins himself acknowledged the existence of so-called "white witches" who used natural herbs for healing magic - though he espoused that even these white witches were entreated by the devil and so the enemy of God. Perkins also recognized that a witch's magic was often used in raising storms and tempests, altering the weather by sea and land, and poisoning the air. ${ }^{7}$ There was, thus, an intricate connection between the natural world, the occult, and the divine in the early modern period, where the study of nature proved to be the most productive route for humans to attempt to discover more about both the occult and divine. But Faustus errs when he takes the significance of the natural world for granted, assuming he has already mastered all the knowledge it might yield. Instead, he attempts to discover mysteries of the divine through occult means, and the result is a downward spiral where he falls from his confident perch of knowing and tumbles into the depths of despair.

According to one seventeenth-century pamphleteer, despair is "a sin that refuses all means of Deliverance... a kind of unkind Ingratitude to Heaven" because those afflicted wrongly come to believe that as they "offended without Remorse, so they should be convicted without Hope... [that] even Infinite Mercy cannot pardon them." ${ }^{8}$ Scholars like Arieh Sachs and Pompa Banerjee argue that Faustus courts the demonic because he already despairs of the fate of his soul, and so the pact with the devil is a mere symptom of his belief

\footnotetext{
${ }^{5}$ For further elaboration on the ties between the natural and social orders, see Michael Stolleis, Natural Law and Laws of Nature in Early Modern Europe: Jurisprudence, Theology, Moral and Natural Philosophy (London: Routledge, 2008).

${ }^{6}$ Thomas Fuller, Abel Redevivus; or, The Dead Yet Speaking: The Lives and Deaths of the Modern Divines (London: Printed by Thomas Brudenell, 1651), Early English Books Online, Wing / F2400, 436.

${ }^{7}$ William Perkins, A discourse of the damned art of witchcraft so farre forth as it is reuealed in the Scriptures, and manifest by true experience (Cambridge: Printed by Cantrel Legge, 1608), Early English Books Online, STC (2nd ed.) / 19697, 128-30. For further reference to the tie between witches' magic and the natural world, see also Mary Floyd-Wilson, "English Epicures and Scottish Witches," Shakespeare Quarterly 57, no. 2 (2006): 131-161.

${ }^{8}$ Anon., Strange and terrible news from Shoreditch of a woman that hath sold her self to the Divel (London: 1674), Early English Books Online, Wing (2nd ed.) / S5831A, 2, 4-5.
} 
in his own damnation. ${ }^{9}$ I tend to disagree with this ordering of things, however. It is not spiritual despair that leads Faustus to summon Mephistopheles - it is intellectual curiosity and ambition. For Faustus is a man who excels in the academic study of the natural world, and he seeks to expand his realm of mastery to the metaphysical world through magic and spells. But he soon realizes his mistake in assuming that the world of the metaphysical can be conquered, understood, or mastered even by one as intellectually capable as he. It is this realization, I argue, that leads him to despair.

Despair played a complicated role in the early modern Protestant faith. The quotation above identifies how despair was considered sinful, a sign of ungratefulness to Heaven which confirmed that one deserved one's damned fate (as falling into despair could also be seen as affirmation of one's reprobate status). But while Protestant ministers warned their congregations against falling into full-on despair, despite the torture of uncertainty surrounding one's spiritual fate, they nonetheless agreed that the temptation to despair could be "spiritually fruitful," as it could encourage people towards repentance and conversion. ${ }^{10}$ Paola Baseotto reframes this distinction as the difference between, on the one hand, the mere "experience of despair that accompanies the realization of the corruption and insufficiency of human attempts to gain forgiveness for sins and salvation" and, on the other, the "abyss of despair" which had "fatal risks, as one may not come out again." 11 Theologians believed that the experience of despair and the deep suffering associated would result in a spiritual re-birth, where the interruption of grace would ultimately bring one back to God - an event that cannot occur without the initial experience of despair. ${ }^{12}$ Arguably, Faustus is met with such an interruption of grace in the form of the Old Man. But Faustus, both reluctant to give up his magical antics and believing he is past the point of redemption, turns the Old Man away.

Faustus is so entrenched in the idea of his own corruption and damnation that he will not be brought back to God, so he will not come out of his despair alive. Faustus demonstrates the

\footnotetext{
${ }^{9}$ Sachs, "The Religious Despair of Doctor Faustus"; Banerjee. "I, Mephastophilis."

${ }^{10}$ Alec Ryrie, Being Protestant in Reformation Britain (Oxford: Oxford University Press, 2013), 32.

${ }^{11}$ Paola Baseotto, "Godly Sorrow, Damnable Despair, and the Faerie Queene I.ix," Cahiers Elisabéthains 69, no. 1 (2006): 1.

${ }^{12}$ It should be noted that this experience of despair was, indeed, fruitful for many Protestants. The seventeenthcentury Baptist John Bunyan, for example, admitted to feeling despair at the prospect of his spiritual fate: "I was driven to my wits end, not knowing what to say, or how to answer these temptations, (indeed I little thought that Satan had thus assaulted me, but that rather it was my own prudence thus to start the question) for that the Elect only attained eternal life, that I without scruple did heartily close withal; but that my self was one of them." Qtd. in Hilary Hinds, "Calvinist Anxiety, Sacred Confidence, and George Fox's Journal," ELH 75, no. 4 (2008): 846. On the potential of Calvinist election and despair to comfort rather than worry early modern Protestants, see also Dewey Wallace, Puritans and Predestination: Grace in English Protestant Theology 1525-1695 (London: Wipf \& Stock, 2004) and Leif Dixon, "Richard Greenham and the Calvinist Construction of God," The Journal of Ecclesiastical History 61, no. 4 (2010): 729-45.
} 
fine line early modern Protestants were asked to walk along the verge of despair-allowing themselves to experience the terrible possibility of their own damnation while nonetheless retaining the hope of being worthy of divine grace (despite the fact that their natural reprobation would likely prevent this result).

The concept of despair was thus imbued with contradiction, as one was expected to inhabit two opposing streams of thought which risked conflicting with and/or overtaking one another. Rather than confirm Protestant caution against entering into despair, regardless of one's place in the election system, Marlowe's play highlights the dangerous potential of the inherent anxieties associated with despair and election. Because even as Protestant ministers advocated for the virtue in doubting one's worthiness of being saved, there was nonetheless the looming possibility that too much doubt could lead one to question not only one's own damnation, but faith in God itself. In her book Believing in Shakespeare: Studies in Longing, Claire McEachern observes how the Protestant insistence on doubt and faith in the abstract concept of God, as opposed to the participatory Catholic spectacles of mass and sacrament, could come up against the human penchant to believe in things. ${ }^{13}$ Article seventeen of the Thirty-Nine Articles of the Protestant faith under Elizabeth I reiterates the anxiety that predestination might cause in those who straddle the thin line between doubt and despair, and how this anxiety might lead them to indulge in temptation: "For curious and carnal persons...to have continually before their eyes the sentence of God's predestination is a most dangerous downfall, whereby the Devil may thrust them either in to desperation or into a recklessness of most unclean living." 14 Faustus is nothing if not curious, and in a time when intellectual discovery was so prominent, he was not alone in his desire to know and explore. The temptation of the devil, therefore, to lure curious men who sought physical and visual satisfaction for their mental wanderings would be particularly likely in the early modern period. ${ }^{15}$ The uncertainty that Calvinism asked people to embrace provided an uncomfortable

\footnotetext{
${ }^{13}$ Claire McEachern, Believing in Shakespeare: Studies in Longing (Cambridge: Cambridge University Press, 2018), 39.

${ }^{14}$ Gerald Bray, ed., Documents of the English Reformation (Minneapolis, MN: Fortress Press, 1994), 297.

${ }^{15}$ Peter Harrison writes about how, in the medieval tradition, intellectual curiosity was a vice linked with lust and desire for forbidden knowledge which risked leading people to immoral paths. Harrison notes how Calvinism takes up similar tropes, emphasizing that it was uncontrolled curiosity that led to Original Sinwhich was ultimately caused by the desire for knowledge about God and election which humans could never be privy to. Harrison also notes that James I writes in Daemonologie about how one's curiosity about mysteries beyond human understanding could lead one to pursue the dark arts. See Harrison, "Curiosity, Forbidden Knowledge, and the Reformation of Natural Philosophy in Early Modern England," Isis 92, no. 2 (2001): 26775. However, I argue that the desire for knowledge about God and the intellectual practices required for Scriptural interpretation in the Protestant tradition nonetheless demand the same kind of curious impulses that Calvin, James, and the medievalists are condemning. It becomes a question of how much curiosity is acceptable, as the impulse to want to know and seek to know is common to both the occult and religion and later, science
} 
basis of belief for men like Faustus. By asking people to abandon visual confirmation of truth in favour of abstract concepts of God and religion, Calvinist predestination created a hole in the fabric of what it meant to believe and have faith — a hole which Catholicism had filled with its emphasis on spectacle, a hole through which the devil and his temptations might easily seep. ${ }^{16}$

My reading of Marlowe's play explores how Faustus, a man who roots his belief in himself in what he is able to achieve through study and mastery of the natural world, struggles when he finds himself enmeshed in a world of the divine and the demonic, without physical anchor to cleave to. Marlowe's God seems to be the God of Calvinist election, and the notable absence of God in the play reflects the uncertainty inherent in ideas about predestination. When Faustus seeks to discover the spiritual mysteries of God, he finds himself inept, and even the power he persuades himself he has obtained by contracting with the devils is based in demonic illusion. There is nothing tangible here, and this becomes disturbing and fatally damning to Faustus. However, the feelings of damnation Faustus feels at the end stem not from religious despair of the fate of his soul, but from his inability to reconcile his metaphysical ambition with his empirical mastery. Genevieve Guenther makes the similar observation that because Faustus is "invested in the idea that spiritual efficacy inheres in the material, in bodies and texts," and because he maintains this form of thinking until the end of the play, he cannot see any chance for his soul to find rest because he cannot imagine a form of living that is not physical. ${ }^{17}$

The more Faustus becomes engrossed in the world of the divine and demonic, the less certain he becomes not only of his spiritual faith, but also in his faith in himself - what he is, and previously was, able to achieve through study of the natural world. The result is a spiritual despair whereby God and the devil become conflated. Salvation and damnation, too, become similarly signified: damnation being the physical destruction of a body torn apart by devils and a soul burnt to ash in the fires of hell, while salvation, as Guenther notes,

\footnotetext{
too. They are points on a spectrum, and it becomes a matter of which outlet provides the greatest satisfaction to one's curiosity in the most accessible medium.

${ }^{16}$ John Parker observes that part of the absence felt after the Reformation was many of the spectacles of the Catholic tradition, including that of confession, which allowed one to pay "lip service" to their sins, and then later revel in them, knowing they would be able to absolve themselves. See Parker, "Faustus, Confession, and the Sins of Omission," ELH 80, no. 1 (2013): 43-45. Protestantism, without the show of the sacraments, denied this absolution to its believers, and the result was the constant uncertainty of whether or not one would be forgiven, saved, ultimately absolved. Protestantism could have been seen to replace the visual spectacles inherent in Catholic practice with a sense of doubt and despair, a void that could only be filled through faith, though faith in such circumstances could prove insufficient.

${ }^{17}$ Genevieve Guenther, "Why Devils Came When Faustus Called Them," Modern Philology 109, no. 11 (2011): 46, 67.
} 
nonetheless entails "self-obliteration into the absolute Otherness of an inscrutable God."18 The only way for him to escape thoughts of the negative abyss surrounding the fate of his soul, whether elect or reprobate, is to seek salvation in the only thing that has ever granted him a sense of stability, the natural world, and he does this in his final monologue. But this desire to immerse himself in the natural world comes too late. Sarah Rivett insightfully notes how Calvinism and Baconian science are but points on a spectrum, both concerned with "a deep awareness of knowledge that could not be known and the compulsion to expand human knowledge nonetheless." ${ }^{19}$ Faustus' intellectual despair ultimately results from trying to expand his knowledge through the abstract concepts of Calvinist faith which cannot be reconciled with his innate desire for satisfaction in the physical world. Instead, he anticipates a need for Bacon's natural philosophy, wherein curious men might satisfy their wonder about spiritual mysteries through the study of the natural world.

When we first meet Faustus he is trying to "settle [his] studies" and he presents the audience with a catalogue of accomplishments in subjects he has mastered (Doctor Faustus 1.1.1). ${ }^{20}$ His language is reflective of his conviction in his own abilities; of analytics and logic as well as medicine, Faustus claims he "hast attained the end" $(1.1 .10,18)$. He further trivializes the pursuit of law as "paltry legacies" (1.1.30). The flippancy with which he dismisses each discipline speaks to his surety, to the point of arrogance, in his own academic ability, particularly when dealing with materiality: the physical body as the "end" of "physick," commercial exchange as the aim of legal study, etc. (1.1.17, 28-29). He looks specifically to tangible proofs of his own mastery, referring specifically to the "bills hung up as monuments," for example, as evidence of his medical expertise (1.1.20). The belief in his own capability to acquire knowledge is evident in his constant use of action verbs in this first monologue: "Faustus...begin ... to sound the depths of that thou will profess/ ...be a divine... / live and die" (1.1.1-5, emphasis mine). All of the verbs he uses are in the active voice to emphasize the credit he gives himself for achieving his own desires.

Some scholars have suggested that the confidence Faustus exhibits in the first half of this monologue wavers when he comes to the subject of theology, particularly when he famously, intentionally, misquotes the verse from the Gospel of John. He emphasizes that "we must sin and so consequently die / ...an everlasting death" but omits the succeeding

\footnotetext{
18 Guenther, 72.

${ }^{19}$ Sarah Rivett, Science of the Soul in Colonial New England (Chapel Hill: University of North Carolina Press, 2011), 24.

${ }^{20}$ Christopher Marlowe, Doctor Faustus: A Norton Critical Edition, ed. David Scott Kastan (New York: Norton, 2005). Quotations from the play refer to the A-Text in this edition.
} 
verses about redemption through repentance (1.1.45-46). ${ }^{21}$ One might assume that this is a sign that, from the start of the play, Faustus experiences religious despair. However, to take his misquotation as an indication of his belief in his own damnation is to overlook Faustus' capability for academic mastery. Rather than suggest that his biblical omission is a sign of his internal hopelessness, I argue it represents the height of his linguistic manipulation - a feat he is only able to achieve because of the training he has received. John Parker supports this observation when he notes that by the sixteenth century, "it was more convenient than ever to provide 'quotation' from the Bible in a more modern sense of the term-verbatim citations of a textual authority used to corroborate sentiments of the quoter's own choosing."22 Faustus leaves the verse incomplete not because he fails to remember it or because he sees no hope in it, but because only the first part serves his purpose which is to justify the turn towards the occult when theology would caution against it. Here, it is evident that Faustus engages in what Sara Munson Deats refers to as "willful self-deceit," which he is only able to do because his theological training has provided him with the expertise necessary to manipulate the Scripture for his own devices. ${ }^{23}$ As Parker notes, "to know the Bible...meant knowing how to break it in pieces," and Faustus' decision to manipulate the line for his own purposes was much closer to the norm at the time than it was a blasphemy. ${ }^{24}$ As such, I argue that he enters into this self-deception intentionally, indeed willingly, largely because it is a space of his own making, an intellectual fabrication that he can create and control.

However, Faustus errs in presuming that magic will be another one of those arenas in which he can excel through material study. He speaks of the occult in the same kind of terms he uses in his previous catalogue, emphasizing the "lines, circles, scenes, letters and characters' for 'these are those that Faustus most desires" (1.1.51-52). He treats the occult as another kind of empirical study, highlighting not its supernatural potential, but the linguistic, visual, material aspects which align it with the academic disciplines to which he is accustomed. He further refers to the practitioner of magic as a "studious artisan" and tells

\footnotetext{
${ }^{21}$ For example, Joseph Westlund argues that Faustus' use of hyperbole here inhibits him because "he makes things worse than they are," which further demonstrates "his inability to believe in the grace and the salvation of Christ." See Westlund, "The Orthodox Christian Framework of Marlowe's Faustus," Studies in English Literature 1500-1900 3, no. 2 (1963): 194.

${ }^{22}$ Parker, "Faustus, Confession, and the Sins of Omission," 33-34.

${ }^{23}$ Sara Munson Deats. "Doctor Faustus: From Chapbook to Tragedy" in Marlowe, Doctor Faustus: A Norton Critical Edition, 210. Rebecca Lemon also recognizes that in this scene "Marlowe intends to call our attention to Faustus' deliberate violation" of the text because of what it reveals about his linguistic and rhetorical mastery. See Lemon, "Scholarly Addiction: Doctor Faustus and the Drama of Devotion," Renaissance Quarterly 69, no. 3 (2016): 881.

${ }^{24}$ Parker, "Faustus, Confession, and the Sins of Omission," 34-35.
} 
himself to "try thy brains to gain a deity" $(1.1 .55,63)$. The repeated emphasis on study as a way to gain knowledge about, and so master, the world reiterates that from the beginning it is through the physical and the material that Faustus sees and understands the world. His interest in magic similarly stems from his desire to increase his academic knowledge about the natural world as well as his power over and in it:

\section{Emperors and kings}

Are but obeyed in their several provinces,

Nor can they raise the wind or rend the clouds;

But his dominion that exceeds in this

Stretcheth as far as doth the mind of man. (1.1.57-63)

Faustus specifically highlights that he wants to supersede rulers who have dominion in only a few areas of the world, as he desires power across the natural world including control over its atmosphere. It is telling that he seeks only to "exceed in this" - that is, in the realm of the natural, material, earthly and human - rather than to simply exceed or excel beyond the world he knows.

It becomes evident that Faustus is looking for answers that reaffirm his own preexistent knowledge - another way for him to revel in his own intellectual mastery. Even at the prospect of having access to great occult power, Faustus can only imagine achieving feats within natural world, those which reflect and parallel the mastery he has already touted in the opening of the play. This is evident when he ruminates with fellow scholars on what he will command his conjured spirits to do:

I'll have them fly to India for gold

Ransack the oceans for orient pearl

And search all corners of the new-found world

For pleasant fruits and princely delicates. $(1.1 .82-85)$

His desires remain within the context and confines of the human, physical, natural world. Even after Faustus summons Mephistopheles and he revels in the possibilities of what he might achieve with the power of the devil, his concept of being a "great emperor of the world" consists of further connecting to and moving within the natural world:

[I'll] make a bridge through the moving air

To pass the ocean with a band of men; I'll join the hills that bind the Afric shore And make that land continent to Spain. (1.3.104-8)

Not only are his desires for material gold and pearl, they centre specifically around the manipulation of the natural world, moving through air, joining hills, and building bridges to 
make exploration of different lands and their geological wonders more accessible to curious men like himself.

It is intriguing that Faustus would seek occult assistance to accomplish more of what he has already achieved - further examination and exploration of the world around him. Why, for example, does he not consider exploring the unknown universe? He engages in discussion with Mephistopheles about the cosmos, but never asks to observe them for himself. Rather, he looks for Mephistopheles to merely verify the theoretical ideas he has already encountered in his study. He asks questions about the shape and movements of the planets, but then haughtily mocks "Tush these slender trifles Wagner can decide. / ... / Who knows not the double motion of the planets?" (2.3.49-51). However, his confidence falters when, looking for another response he can reconcile with his pre-existing knowledge, he asks Mephistopheles, "Tell me, where is the place that men call hell?" (2.1.112). While Faustus expects to hear about a hell that is, as Guenther suggests, "an extension of the university" 25 or some such place that he can mentally locate or visually conceive, he instead receives an unsettling response from the devil:

Hell hath no limits, nor is circumscribed In one self place, for where we are is hell, And where is hell, there we must ever be. (2.1.117-19)

By refusing (and, indeed, being unable) to situate hell in a particular place, Mephistopheles severely complicates Faustus' understanding by revealing that there are things, even with occult magic, that he cannot fully understand. His metaphysical answer seems to disturb Faustus who anchors his intellect not in higher concepts - recall that he treats even theology as an academic discipline - but in empirical, worldly ideas. This disruption to Faustus' conventional way of thinking is evident in the fact that he immediately dismisses Mephistopheles' description: “Come, I think hell's a fable / ...these are trifles and mere old wives' tales" $(2.1 .123,131)$. Despite Mephistopheles' insistence that "I am an instance to prove the contrary," Faustus declares they should 'leav[e] off' the subject and immediately proceeds to ask the devil for a wife $(2.1 .132,136)$.

Mephistopheles, too, has a vested interest in redirecting the conversation, lest Faustus become overly consumed with thoughts of heaven and hell which risks the possibility of him returning to God, something Mephistopheles is determined to prevent. But procuring Faustus a wife would introduce an unpredictable variable into Mephistopheles' quest for Faustus'

\footnotetext{
${ }^{25}$ Guenther, "Why Devils Came When Faustus Called Them," 60.
} 
soul. A wife would mean another potential influence in Faustus' life, one that might impede his immoral trajectory. Moreover, marriage is a holy sacrament, another religious "ceremonial toy," as Mephistopheles describes it, which will nonetheless link Faustus to the Christian faith through ritual (2.1.146). Faustus is evidently looking for an earthly distraction from his metaphysical doubts, and Mephistopheles offers him one in a form Faustus likes best: books. After dismissing Faustus' inquiry about a wife, encouraging him to pursue lechery instead, Mephistopheles hands him another book of magic, highlighting the "iterating of these lines [that] brings gold" and "this circle on the ground [that] / Brings whirlwinds, tempests, thunder, and lightning" (2.1.156-58). Here, Mephistopheles attempts to draw Faustus' eye towards the same visual emblems that fascinated him initially - the "lines, circles, scenes, and characters" that Faustus did most desire (1.3.51). And the strategy works. Faustus willingly takes the book and asks for two more, one "where [he] might see / All characters and planets of the heavens, / That I might know their motions and dispositions" and one "wherein [he] might see all plants, herbs, and tress that grow upon the earth" (2.1.165-67, 170-71). This scene with the books is intriguing for several reasons. It allows Faustus to reiterate his partiality towards the material, physical world, both in the tangible books themselves and in their contents. For the focus of these books is largely on the natural world and order of the universe which humans can study and attempt to understand through logic and observation - realms in which Faustus excels. But perhaps more significantly, this scene becomes a kind of metonym for Faustus' evolution as the play progresses. While he begins enamored with the lines and circles of demonic magic, such as those in the book Mephistopheles gives him first, his grand plans for commanding spirits soon devolve into questions about the cosmos and the heavens which straddle the lines between empirical and mysterious (such is the topic of the second book Faustus requests). But when those questions become too disturbing, too despairing for a man who is accustomed to the pursuit of inductive intellectual knowledge, Faustus turns back to the natural world in his final plea to become one with the earth and its elements at the most basic levels - like the plants and trees in book three. From the start of Act Two then, Faustus' own desires for knowledge plot out his downfall and betray his yearning for knowledge which, at its core, is not occult or even celestial, but natural.

The books prove to be a temporary distraction, a quick remedy to stroke his intellectual ego. But it becomes evident that Faustus cannot escape the limitations of his knowledge about the spiritual mysteries. His mind soon wanders beyond material confines back to the metaphysical, and to his surprise, he encounters an obstinate Mephistopheles 
when he asks, "Tell me who made the world?" (2.3.64). The devil twice refuses: "I will not. / ... / Move me not, for I will not tell thee" (2.3.65-67). Mephistopheles' response is almost trepidatious, not only of the possibility that thinking about God will lose him Faustus' soul for hell, but of the very idea of God Himself. His refusal further indicates that not only will Mephistopheles not answer, he cannot answer, not truly. For God remains a mystery even to those within the celestial sphere, and the devil's implicit lack of knowledge only exacerbates the limitations of Faustus' human knowledge, not only of what he has, but also of what he can ever hope to gain. While scholars like Westlund imply that Faustus' misquotation of Scripture is a result of his despair, I believe that Faustus only begins his descent into despair once he encounters Mephistopheles, who forces him to consider otherworldly concepts, truths which Faustus cannot understand because he is limited with human knowledge. His confrontation with these difficult metaphysical truths catapults Faustus into a disturbing realm of uncertainty, and this is perhaps most evident in the way he oscillates between keeping his contract with the devils and repenting:

Now, Faustus, must thou needs be damned And canst thou not be saved.

What boots it then to think of God or heaven?

Away with such vain fancies and despair.

Despair in God and trust in Beelzebub.

Now go not backward; no, Faustus, be resolute.

Why waverest thou? O, something soundeth in mine ears:

"Abjure this magic; turn to God again!"

Ay, and Faustus will turn to God again.

To God? He loves thee not.

The god thou servest is thine own appetite,

Wherein is fixed the love of Beelzebub. (2.1.1-12)

While never unsure of his ability to master logic, law, and medicine, here for the first time Faustus demonstrates worry for a part of himself he cannot manipulate for his own purposes: his soul. He also begins to express a doubt that has thereunto been absent from his character as he openly wavers between thoughts of God and the devil, between salvation and damnation. This conflict becomes further apparent in the sharp shifts in his language as Faustus struggles with integrating spiritual mysteries into his material perception of the world. This drastic turn in his language and mood is evident when Mephistopheles refuses to respond to his question about the world's creator. After the first refusal, Faustus tries to entice the devil, entreating "Sweet Mephistopheles, tell me" (2.3.66). But when the devil remains insistent in his opposition, and implicitly reveals the fragility of his own uncertainty about God in so doing, Faustus becomes evidently frustrated and flustered. Barely six lines 
following his "sweet" flattery, Faustus lashes out, telling the "accursed spirit [to] go to ugly hell!" and threatening to turn towards "God that made the world" (2.3.71-72).

Here, Faustus again foreshadows the means of his salvation without realizing it. It may seem, at first, that Faustus is inevitably doomed because of the paradoxical situation in which he finds himself, as many humans do - to be an innately curious being who can never be fully satisfied because there is some knowledge, of God and other such spiritual mysteries, he will never be able to attain. And it may be that the imposition of this limitation on knowing, whether knowing truly "who made the world" or knowing the truth of one's spiritual fate, is what makes the God in Faustus appear so cruel and distant. Faustus' God reflects the anxieties and uncertainties underpinning Calvinist ideas of predestination and election, and, thus, seems to warrant the critical examination brought upon Him and His Calvinist ministers by writers like Marlowe. But, intriguingly, Marlowe does not leave Faustus lamenting the limitations of his knowledge in the end. Instead, Faustus longs to return to the earth, to become part of the mountains and hills that might bury him and save his soul from a tormented fate. ${ }^{26}$ This return to the natural world is significant. It suggests that there may yet have been another way for Faustus to find his salvation, to discover God-not by seeking the God of Calvinist election, who can feel absent and unreliable, but by looking for truth in the God of Creation-He who made the world-by focusing on creation itself.

This idea of contemplating God through His Creation stems from the work of Francis Bacon, who led the charge towards the legitimation of natural philosophy as a reputable science in seventeenth-century England. Bacon sought to validate the 'new science' by linking it with theology. More significantly, he strived to marry empirical experimentation to theological questioning in a way that superseded the use of reason alone for discovering truths about God. ${ }^{27}$ The result, as Robert Watson succinctly articulates it, was that Baconian science promoted replacing "questions about ultimate truths with questions about the world as practically manifest, to focus on the transaction one finds reliable with the externalities of

\footnotetext{
26 "Mountains and hills, come, come and fall on me / And hide me from the heavy wrath of heaven. / No? Then I will run headlong into the earth. / Gape, earth!" (5.2.150-53).

${ }^{27}$ See Francis Bacon, The novum organum of Sir Francis Bacon, Baron of Verulam, Viscount St. Albans, epitomiz'd for a clearer understanding of his natural history (London: Thomas Lee, 1677) Wing / B311, Early English Books Online. Peter Harrison notes how in the twelfth century, Thomas Aquinas had suggested that human reason alone could allow people to discover certain truths about God, which later came to be known as "natural theology." Bacon attempts to link Aquinas' theory to scientific study of the natural world to expand the ways in which humans might use intellect to know and discover truths about God. See Harrison, "Natural Theology, Deism, and Early Modern Science," 427-28.
} 
that world." 28 The aim was to locate the existence of God by using reason and scientific induction to observe and understand patterns in the natural world He created. Divine design would reveal itself in the organization of nature. ${ }^{29}$ Natural philosophers like Bacon, Johannes Kepler, and Robert Boyle advocated this as the most effective method by which humans might recuperate the knowledge of God and His spiritual mysteries that was lost to the descendants of Adam and Eve at the Fall. ${ }^{30}$ Peter Harrison notes that Bacon's natural philosophy was criticized by theologists who accused the new science of "desacrilization" by attempting to divest the natural world of the celestial ontology of its maker. However, Harrison also acutely suggests that this desacrilization more likely stemmed from the Reformation itself, as Protestantism's “critical stance towards the sacraments and the cult of saints and its denial of contemporary miracles...promoted the emergence of modern science by creating a space in the material world for naturalistic explanation." ${ }^{11}$ I see Harrison's estimation of Protestantism's “desacrilization” as coalescent with Claire McEachem's aforementioned observation of the human tendency to believe in things. Protestantism's insistence on abstract faith without tangible manifestation challenges this innately human inclination towards the material and the visual in problematic ways, such that it risks losing people like Faustus to temptations that nonetheless satisfy the need for more concrete displays of belief. Bacon's natural philosophy, however, fills in the gap that Catholic spectacle left in Reformation faith. It provides a new route to God through the material, natural world - a method of pursuing spiritual truths through tangible means, so the believer can sustain the kind of active participation in their faith which Calvinist predestination complicates. ${ }^{32}$

\footnotetext{
${ }^{28}$ Watson, Back to Nature, 19.

${ }^{29}$ Harrison, "Natural Theology, Deism, and Early Modern Science," 429. See also Francis Bacon. The Works of Francis Bacon, 14 vols, ed. James Spedding, Robert Leslie Ellis, and Douglas Denon Heath (London: Longman, 1857-74).

${ }^{30}$ Harrison, "Physico-Theology and the Mixed Sciences," 170, 179; Harrison, "Natural Theology, Deism, and Early Modern Science," 429. For more information on theories about lost human knowledge and the biblical Fall of Adam and Eve, see Peter Harrison, "Original Sin and the Problem of Knowledge in Early Modern Europe," Journal of the History of Ideas 63, no.2 (2002): 239-259. See also Robert Boyle, Some Considerations Touching the Usefulness of Experimental Natural Philosophy (London: H. Herringman, 1663), Wing / B4030, Early English Books Online, and Johannes Kepler, Johannes Kepler Gesammelte Werke, 20 vols, ed. W. von Dyck and M. Caspar (Munich: C. H. Beck, 1938).

${ }^{31}$ Harrison, "Natural Theology, Deism, and Early Modern Science," 431.

${ }^{32}$ It is important to note that Bacon sought to placate critics who based their opposition to natural philosophy on the dangers of "curiosity" by differentiating "legitimate knowledge from nature" from "vain pleasures of curiosity." It is the former, "knowledge sought for truth of the nature of the world," which brings one closer to God. See Harrison, "Curiosity, Forbidden Knowledge, and the Reformation of Natural Philosophy," 279-80. Faustus evidently seeks knowledge at the start of the play for vain pleasure, to increase his own catalogue of knowing for boastful, prideful reasons. His reasons for experimenting within the natural world and its order is not, therefore, very Baconian, but I do argue that as the play progresses, particularly during his interrogation of
} 
For Bacon, part of the void in Calvinism stemmed from the overemphasized dependence on words, particularly those of Scripture. Faith in God based on words alone produced empty signifiers, signals towards truths that lacked any concrete or material substance in which people might invest themselves. He calls "the first distemper of learning, when men study words and not matter." 33 Faustus exhibits the dangers of relying on empty signifiers, as what starts as a fascination with the written emblems of the spell book increasingly devolves into a paralyzed rhetoric, devoid of meaning or action or, indeed, the capability for action. Barbara Traister observes that while at the beginning Faustus' "power lies in his words" and he seems "intoxicated by his own rhetoric," as the plot continues "the general sense of loss in the play is the ....failure of action to live up to words." ${ }^{34}$ His intoxicated rhetoric manifests in the active verbiage he uses to express his self-assurance in his own abilities, but as that confidence disintegrates his language becomes less tied to his own capability to act. While he continues to outwardly assert a linguistic boldness that resembles the confident Faustus we see at the start of the play, the significant difference is that he displays such boldness only around Mephistopheles to maintain the illusion that he possesses the same self-security which he has always had. The irony, of course, is that this active language, once reflective of Faustus' certainty in his own capability to acquire knowledge, becomes an overcompensation for the decreased self-confidence he experiences under the contract:

Have not I made blind Homer sing to me Of Alexander's love and Oenone's death?

And hath not he that built the walls of Thebes

With ravishing sound of his melodious harp

Made music with my Mephistopheles?

Why should I die then or basely despair? (2.3.26-31)

The form and content of this speech closely resembles the first monologue of the play where the audience is introduced to Faustus as he touts his various academic accomplishments. The key difference, however, is that unlike in the first catalogue, Faustus cannot claim credit for

\footnotetext{
Mephistopheles about metaphysical truths, that Faustus demonstrates an increasing desire to know for spiritual reasons, particularly regarding the fate of his soul. As he ruminates on the absence, presence, and nature of God and His Mercy, Faustus manifests his desire to unlock spiritual mysteries that have thereunto eluded him in order to ascertain a kind of comfort and assurance about both his earthly and after lives. This desire to know about God supersedes vanity, and, I argue, makes Faustus a candidate for Bacon's philosophical method of attempting to know God through the study of the natural world.

${ }^{33}$ Francis Bacon, Francis Bacon: A Selection of His Works, ed. Sidney Warhaft (Indianapolis: Bobbs-Merrill, 1982), 232.

${ }^{34}$ Barbara Traister, Heavenly Necromancers: The Magician in English Renaissance Drama (New York: University of Missouri Press, 1984), 106, 94, 96.
} 
any of the feats he lists here as it is Mephistopheles who has the power to manifest the dead Homer. Faustus only communicates his desires to Mephistopheles who is the one with the ability to act on those words - something Faustus himself proved capable of only prior to his encounter with the devils. This is where the change in his language becomes significant. Before, Faustus could ask himself "hast thou not attained" mastery over multiple spheres of worldly knowledge, confident that he himself had achieved these things. But after his first encounter with Mephistopheles he begins to defer to his devil companion to perform the great feats that he believed himself once capable of doing alone. After Mephistopheles first appears, Faustus begins to imagine his various impending triumphs, but he admits:

Had I as many souls as there be stars

I'd give them all for Mephistopheles.

By him I'll be a great emperor. (1.3.102-4, emphasis mine)

The idea that Faustus can only ever achieve anything magical with Mephistopheles' power echoes again in the large quotation above, where the builder of Thebes made music "with" Mephistopheles. The preposition connotes not only partnership, but facilitation (as synonymous with the above "by"), as though Mephistopheles was involved in the music making both as a musician and as the conductor of the whole affair.

The tragic irony of Marlowe's play is that Faustus attempts to combat his religious despair by using magic to affirm his capability for greatness, but magic has the opposite effect. Instead, his engagement with the occult initiates intellectual and religious despair which operate in positive correlation, as the more he yields the command of mastery to Mephistopheles - because of his increasing lack of confidence in his own ability to acquire and reconcile different knowledge - the more concerned he becomes with the fate of his soul. ${ }^{35}$ His despair at the likelihood of being damned causes him to turn away from God in favour of serving his own appetite. However, by turning away from God Faustus does not become his own master; rather, he replaces one master for another. By submitting himself to Mephistopheles' power, Faustus enlists himself in the service of another spiritual figure, the presence of whom only increases his awareness of the damnation he seeks to evade contemplating. ${ }^{36}$ His constant deference to Mephistopheles and the increasing discrepancy

\footnotetext{
${ }^{35}$ When I suggest that the two despairs operate in positive correlation, I am referring to the fact that they occur alongside one another and that they are most strongly related because of the ways they contribute to Faustus' conflict between the fate of his soul and his penchant towards earthly knowledge. Admittedly, I am unsure whether the two despairs are related beyond this shared effect on Faustus, though I believe their parallel progression contributes to a fascinating study of the protagonist.

${ }^{36}$ For related observations, see Constance Brown Kuriyama, Hammer or Anvil: Psychological Patterns in Christopher Marlowe's Plays (New York: Rutgers University Press, 1980). Kuriyama writes that "the
} 
between his words and his ability to perform real action also demonstrates that as Faustus becomes more involved with the devils, the less certain he becomes about both his intellectual capability and the fate of his immortal soul.

As he further entangles himself in the devils' web, thoughts of damnation continue to plague him. Alone again a few scenes later, he laments:

My heart's so hardened I cannot repent.

Scarce can I name salvation, faith, or heaven,

But fearful echoes thunder in mine ears

Faustus, thou art damned. Then swords and knives,

Poison, guns, halters, and envenomed steel

Are laid before me to dispatch my self,

And long ere this I should have slain my self,

Had not sweet pleasure conquered deep despair. (2.3.18-25)

Here Faustus seems to contradict himself in another display of the disconnection between his words and reality. He begins by admitting his fear of God because of what he believes to be his own damned fate, and yet he concludes by claiming that his despair has been conquered by the various pleasures his devilish bond has afforded him. However, the fact that he continues to contemplate the fate of his soul is proof of the contrary - that despite his bond he cannot escape his fear of the spiritual fate awaiting him. Moreover, the fact that he is given the physical tools to end his life, and so end such internal struggle for good, yet cannot bring himself to do so further speaks to his decreasing ability to act, especially as he claims that he avoids such desperate action on account of his supposedly "conquered" despair which, as we have seen, is not quite so.

Despite Faustus' claims to the contrary, his despair continues as the play progresses, as his anxiety about the fate of his soul begins to taint even the small pleasures magic afforded him only a few scenes earlier. Such is evident in the first scene of Act Four during Faustus' interaction with the horse-courser. His playful mood suddenly turns aggressive; he changes from immersing himself in the joke at the horse-courser's expense, warning him not to ride the horse in the water, to showing unexpected agitation: "Away you villain! What, dost think I am a horse-doctor?" (4.1.121-30). His use of exclamation and his inflammatory language against the unsuspecting horse-courser indicate a sharp alteration in tone which seems to reflect the transition of his thought from the trivial joke to the fate of his soul; for in the next line Faustus embarks on an existential contemplation: "What art thou, Faustus, but a

fundamental irony of the play is that Faustus, in trying to escape one set of restraints, has only implicated himself in another set that derives from and parodies the original" (125). 
man condemned to die?" (4.1.131). It is as though he tires of his game, recognizing it to be a mockery of the kind of magnificent works he had once hoped to achieve with magic.

His diminished sense of mastery over the physical world around him, the manifestation of intellectual despair, sparks a renewed contemplation of his religious despair as he admits "Despair dost drive distrust into my thoughts" (4.1.134). But the nature of the relationship between his intellectual and religious despairs begins to change as the question of who Faustus distrusts becomes ambiguous. It is telling that his initial religious despair is a result of his fear of Marlowe's Calvinist God who would see him damned-whether as punishment for his sins or simply being born reprobate. And yet, despite his earlier declaration that he has nothing to fear from Mephistopheles, it soon becomes obvious to him that the devils engage in the same kind of fearful control that caused him to turn from God. In another of his debates about repentance the evil angel assures Faustus that "if thou repent, devils shall tear thee in pieces" and as soon as Faustus cries out to Christ to "save my distressed soul" Lucifer appears as a menacing reminder of the commitment Faustus has made and the impossibility of breaking it without painful consequences $(3.1 .77,80)$. Faustus then finds himself trapped in his contract with the devils and doomed to his increasing reliance on Mephistopheles to aid him in his exploits. Just as he does not believe he can effect change to the fate of his soul, so he begins also to doubt his ability to accomplish anything alone as he used to. The more entrenched Faustus becomes in his religious despair, both in the possibility of his damnation and in his servitude to the devils, the less masterful his ambitions are (coinciding with the rise of his intellectual despair). The great feats he desires at the start of the play devolve into parlour tricks and childish pranks: petty revenge against a knight who insults him, infantile games of deceit with a simple and unsuspecting horse-courser (4.1.73-93, 105-79). No longer does he seek to conquer and colonize, to raise armies and advise kings, but these magnificent desires are replaced by a desperation to impress, to show that he is, in fact, still capable of any kind of achievement. He brings forth the image of Alexander the Great in order to "sufficiently content" the Emperor and to “delight [him] with some mirth" (4.1.54, 86-87). Faustus inadvertently takes on another submissive role and so his initial dreams of mastery and control surrender to the prospect of political favour. ${ }^{37}$ Faustus's thoughts of mastery disappear altogether by the end of the play which, I argue, is a result of the coinciding spiritual uncertainty he battles as "Hell strives with grace for conquest in [his] breast" (5.1.64). However, his experience with fear of both

\footnotetext{
${ }^{37}$ This occurs again with the Duke who himself notes Faustus' "courteous intent to pleasure me" (4.2.8).
} 
heaven and hell creates a parallel rather than an opposition between the two, so that the uncertainty he feels is not about salvation or damnation, but about the afterlife as a whole. Both God and the devils engender despair and distrust which Faustus cannot shake as the only element he might have used to combat them - his own capability for mastery, his certainty in himself as an accomplished academic of the physical world-has been surrendered in his futile attempts to evade confronting his eternal fate.

By making God and the devils two sides of the same coin Marlowe effectively reconfigures the nature of Faustus' struggle. It is not necessarily a battle between the forces of good and evil, but one between, as John D. Cox notes "religious belief or unbelief, where the stakes are...between worldly success and eternal damnation." 38 Until the final monologue the play positively correlates Faustus' religious despair for his soul and the intellectual despair of his decreasing sense of his own ability to know and absorb knowledge. However, the two trajectories diverge at the end because Faustus comes to view God and the devils in the same light. The contrary nature of ideas surrounding Protestant despair lay in the expectation that people would act is if they were worthy of being saved by God, despite accepting the fact that they were likely damned. But if God and Lucifer come to mean similar things then arguably salvation and damnation, too, become similarly signified. Religious despair, then, is not a case of lacking grace, but of lacking hope altogether. As the play demonstrates, Faustus finds only despair, fear, and self-doubt in his engagement with the spiritual, divine or otherwise, which suggests that rather than being a conduit for repentance and salvation, even the experience of despair can be harrowing and damning. Faustus responds to this bleak position by redirecting his thoughts towards the earthly, material world - the only sphere in which he can affirm his own capability for intellectual mastery. He repudiates the idea of God in his final soliloquy, whom he still views with fear and mistrust even as he faces a damnable alternative: "And see, where God / Stretcheth out his arm and bends his ireful brows! / ... / ...hide me from the heavy wrath of God!” (5.2.77-81). ${ }^{39}$ And even as he claims he will "leap up to my God," his hopefulness is only temporary because thoughts of God are equated with thoughts of the devil and so of torment and damnation (5.2.71). Faustus blurs the lines between heaven and hell, between God and Lucifer, when he says "rend not my heart for naming of my Christ! / Yet will I call on him. O spare me, Lucifer!" (5.2.76-77). Faustus' paralleling of Christ and the devil reflects his consideration of

\footnotetext{
${ }^{38}$ John D. Cox, The Devil and the Sacred in English Drama 1350-1642 (Cambridge: Cambridge University Press, 2000), 123.

${ }^{39}$ See Kuriyama, Hammer or Anvil, 100.
} 
them as part of the same problem — as promulgators of a despair which inhibits one's ability to find and maintain self-assurance in the world they know.

It is also telling that Faustus attempts to understand the spiritual in terms of tangible concepts that he can mentally digest. He references Christ's blood specifically, noting that "One drop would save my soul" as he can only conceive of salvation in earthly terms while the otherwise abstract, transcendent nature of being saved escapes him and causes the wavering uncertainty and doubt we see so often in his self-debates (5.2.74-75). And when he does eventually think of his eternal soul as his final hour comes to a close, he cries out for "Mountains and hills, come, come and fall on me, ... Then will I run headlong into the earth" $(5.2 .80,82)$. When at the start of the play Faustus summons Mephistopheles and the devils in a similar way_-CCome Mephistopheles / Veni, veni, Mephistophile!"- by the end he rejects such spiritual summons in favour of the earthly_ “Come not, Lucifer!"-wishing the earth would swallow him up so that he might return fully to it (2.1.27-28; 5.2.115, emphasis mine). In essence, Faustus is asking for a physical burial without spiritual consequences, to return wholly to the material earth while forsaking any form of afterlife. His desire to be dissolved back into nature demonstrates his repudiation of the spiritual afterlife, the thoughts of which have inflated his religious despair and, consequently, shattered the confidence of a once capable, fruitfully curious intellect. And though he begins by wanting to master the natural elements, his concluding speech signals a desire to be mastered by them in a final surrender to the physical world he foolishly took for granted. ${ }^{40}$ Cleanth Brooks similarly observes that in this final soliloquy Faustus' concern 'is with holding back the clock, not in changing his relation to God." 41 Indeed, he asks that the final hour might be "a year, a month, a week, a natural day," and yet "Time runs and the clock will strike" $(5.2 .68,70)$. The clock becomes a physical signifier for Faustus to try and rationalize the idea of time - not only the time he has left, but the concept of eternity which looms before him terrifying and completely incomprehensible. Thus, as his religious despair evolves from a fear of damnation to a fear of the celestial, it is his intellectual despair which takes him over as he laments the world of empirical study he has forsaken in order to pursue a curiosity of higher truths which could never be satisfied by reason alone.

\footnotetext{
${ }^{40}$ Rebecca Lemon agrees that in the end Faustus' desires are oriented towards pursuing a path for life — not salvation, but earthly life. See Lemon, "Scholarly Addiction," 866.

${ }^{41}$ Cleanth Brooks, "The Unity of Marlowe's Doctor Faustus," in Marlowe, Doctor Faustus: A Norton Critical Edition, 290.
} 
In the end, Faustus finds comfort not in God or even in Lucifer, but in the natural world. With his final pleas to the hills and the mountains, Faustus' intellectual despair takes precedence over Protestant despair, as he reveals that what he most desires, what he innately craves, is the material reassurance of belief — belief in himself and, I argue, belief in a God he might hope to understand through study. For the world of earthly knowledge represents the only place Faustus feels secure, certain, free of the debilitating uncertainty religious despair engenders. While much of the play parallels Faustus' spiritual and intellectual struggles, in the end, it becomes evident that there is only one realm in which Faustus might have found salvation - if not through election, then, at the very least, through the satisfaction of discovering spiritual comfort within the natural design of God's Creation. By exploring what Jonathan Dollimore notes is the tension between moral structures and the Renaissance focus on knowledge, where "the search for knowledge becomes a search for security among the uncertainty promulgated by cherished orthodoxies," Doctor Faustus highlights that abstract faith may not always be enough. Sometimes, one needs to know that there is something to believe in. ${ }^{42}$

\section{Bibliography}

Anon. Strange and terrible news from Shoreditch of a woman that hath sold her self to the Divel. London: 1674. Wing (2nd ed.) / S5831A. Early English Books Online.

Bacon, Francis. The novum organum of Sir Francis Bacon, Baron of Verulam, Viscount St. Albans, epitomiz'd for a clearer understanding of his natural history. London: Thomas Lee, 1677. Wing / B311. Early English Books Online.

- The Works of Francis Bacon. 14 vols. Edited by James Spedding, Robert Leslie Ellis, and Douglas Denon Heath. London: Longman, 1857-74.

- Francis Bacon: A Selection of His Works. Edited by Sidney Warhaft. Indianapolis: Bobbs-Merrill, 1982.

Banerjee, Pompa. "I, Mephastophilis: Self, Other, and Demonic Parody in Marlowe's Doctor Faustus." Christianity \& Literature 42, no. 2 (1993): 221-41

Baseotto, Paola. “Godly Sorrow, Damnable Despair, and the Faerie Queene I.ix.” Cahiers Elisabéthains: A Journal of English Renaissance Studies 69, no. 1 (2006): 1-11.

\footnotetext{
42 Jonathan Dollimore, Radical Tragedy: Religion, Ideology, and Power in the Drama of Shakespeare and his Contemporaries, $3^{\text {rd }}$ ed. (New York: Palgrave Macmillan, 2010), 323, 328.
} 
Boyle, Robert. Some Considerations Touching the Usefulness of Experimental Natural Philosophy. London: H. Herringman, 1663. Wing / B4030. Early English Books Online.

Bray, Gerald, ed. Documents of the English Reformation. Minneapolis, MN: Fortress Press, 1994.

Brooks, Cleanth. "The Unity of Marlowe's Doctor Faustus." In Marlowe, Doctor Faustus: A Norton Critical Edition, 281-91.

Cox, John D. The Devil and the Sacred in English Drama 1350-1642. Cambridge: Cambridge University Press, 2000.

Deats, Sara Munson. “Doctor Faustus: From Chapbook to Tragedy.” In Marlowe, Doctor Faustus: A Norton Critical Edition, 209-25.

Dixon, Leif. "Richard Greenham and the Calvinist Construction of God." The Journal of Ecclesiastical History 61, no. 4 (2010): 729-745.

Dollimore, Jonathan. Radical Tragedy: Religion, Ideology, and Power in the Drama of Shakespeare and his Contemporaries. $3^{\text {rd }}$ ed. New York: Palgrave Macmillan, 2010.

Floyd-Wilson, Mary. “English Epicures and Scottish Witches.” Shakespeare Quarterly 57, no. 2 (2006): 131-161.

Fuller, Thomas. Abel Redevivus; or, The Dead Yet Speaking: The Lives and Deaths of the Modern Divines. London: Thomas Brudenell, 1651. Wing / F2400. Early English Books Online.

Guenther, Genevieve. "Why Devils Came When Faustus Called Them.” Modern Philology 109, no. 11 (2011): 46-70.

Harrison, Peter. "Curiosity, Forbidden Knowledge, and the Reformation of Natural Philosophy in Early Modern England.” Isis 92, no. 2 (2001): 265-90.

—. "Original Sin and the Problem of Knowledge in Early Modern Europe." Journal of the History of Ideas 63, no. 2 (2002): 239-259.

—. "Physico-Theology and the Mixed Sciences." In The Science of Nature in the Seventeenth Century: Patterns of Change in Early Modern Natural Philosophy, edited by Peter R. Anstey and John A. Schuster, 165-83. New York: Springer, 2005.

—. "Natural Theology, Deism, and Early Modern Science." In Science, Religion, and Society: An Encyclopedia of History, Culture, and Controversy, edited by Arri Eisen and Gary Laderman, 426-40. New York: Routledge, 2007.

Hinds, Hilary. “Calvinist Anxiety, Sacred Confidence, and George Fox's Journal.” ELH 75, no. 4 (2008): 841-70. 
Kepler, Johannes. Johannes Kepler Gesammelte Werke. 20 vols. Edited by W. von Dyck and M. Caspar. Munich: C. H. Beck, 1938.

Kuriyama, Constance Brown. Hammer or Anvil: Psychological Patterns in Christopher Marlowe’s Plays. New York: Rutgers University Press, 1980.

Lemon, Rebecca. "Scholarly Addiction: Doctor Faustus and the Drama of Devotion." Renaissance Quarterly 69, no. 3 (2016): 865-98.

Marlowe, Christopher. Doctor Faustus: A Norton Critical Edition, edited by David Scott Kastan. New York: Norton, 2005.

McEachern, Claire. Believing in Shakespeare: Studies in Longing. Cambridge: Cambridge University Press, 2018.

Parker, John. "Faustus, Confession, and the Sins of Omission." ELH 80, no. 1 (2013): 29-59.

Perkins, William. A discourse of the damned art of witchcraft so farre forth as it is reuealed in the Scriptures, and manifest by true experience. Cambridge: Cantrel Legge, 1608. STC (2nd ed.) / 19697. Early English Books Online.

Rivett, Sarah. Science of the Soul in Colonial New England. Chapel Hill: University of North Carolina Press, 2011.

Ryrie, Alec. Being Protestant in Reformation Britain. Oxford: Oxford University Press, 2013.

Sachs, Arieh. "The Religious Despair of Doctor Faustus." The Journal of English and Germanic Philology 6, no. 4 (1964): 625-47.

Stolleis, Michael. Natural Law and Laws of Nature in Early Modern Europe: Jurisprudence, Theology, Moral and Natural Philosophy. London: Routledge, 2008.

Traister, Barbara. Heavenly Necromancers: The Magician in English Renaissance Drama. New York: University of Missouri Press, 1984.

Wallace, Dewey. Puritans and Predestination: Grace in English Protestant Theology 15251695. London: Wipf \& Stock, 2004.

Watson, Robert. Back to Nature: The Green and the Real in the Late Renaissance. Philadelphia: The University of Pennsylvania Press, 2006.

Westlund, Joseph. "The Orthodox Christian Framework of Marlowe's Faustus." Studies in English Literature 1500-1900 3, no. 2 (1963): 191-205. 